\title{
Application of standard and novel prog- nostic systems in patients with myelodys- plastic syndrome undergoing allogeneic hematopoietic stem cell transplantation
}

\author{
Elena V. Morozova, Maria V. Barabanshikova, Nikolai Yu. Tcvetkov, Ksenia V. Melsitova, Julia V. Rudnitskaya, \\ Elena I. Darskaya, Sergey N. Bondarenko, Ivan S. Moiseev, Boris V. Afanasyev \\ R. Gorbacheva Memorial Research Institute for Pediatric Oncology, Hematology and Transplantation, \\ The First Pavlov St. Petersburg State Medical University, St. Petersburg, Russian Federation \\ Dr. Maria V. Barabanshikova, PhD, R. Gorbacheva Memorial \\ Research Institute for Pediatric Oncology, Hematology and \\ Transplantation, 6-8 L. Tolstoy St, 197022, St. Petersburg, \\ Russia \\ Phone: +7 (911) 1640157 \\ Fax: +7 (812) 2340616 \\ E-mail: maria.barabanshikova.spb@gmail.com, \\ mashaprian@mail.ru
}

Citation: Morozova EV, Barabanshikova MV, Tcvetkov NY et al. Application of standard and novel prognostic systems in patients with myelodysplastic syndrome undergoing allogeneic hematopoietic stem cell transplantation. Cell Ther Transplant 2019; $8(1): 36-45$.

\section{Summary}

Several prognostic indexes were developed to predict outcome in patients with myelodysplastic syndrome (MDS). The aim of our study was to evaluate prognostic impact of disease- and transplant-specific indexes on the results of allogeneic hematopoietic stem cell transplantation (allo-HSCT) in MDS patients.

\section{Patients and methods}

A retrospective cohort of fifty-nine MDS patients (excluding secondary acute myeloid leukemia) and treated with allo-HSCT was used to evaluate the predictive value of the following prognostic indexes: IPSS, IPSS-R, WPSS, Disease Risk Index (DRI), prognostic systems developed by Kroeger et al., Armand et al., Pretransplant Assessment of Mortality Score (PAM), EBMT risk score and Hematopoietic Cell Transplantation-specific Comorbidity Index (HCT-CI).

\section{Results}

There was a significant difference in risk estimation between indexes $(\mathrm{p}<0.001)$. Clinical factors significant for overall survival (OS) in the univariate and multivariate analyses were as follows: acute graft-versus-host disease (GVHD) grade I-II (HR 0.223, 95\% CI 0.059-0.721, $\mathrm{p}=0.0134)$ and occurrence of sepsis during aplasia (HR 3.636, 95\% CI 1.438-8.673, $\mathrm{p}=0.0059$ ). Despite significant impact of CD34+ cell contents in hematopoietic graft $(\mathrm{p}=0.006)$ revealed in ROC analysis, only DRI remained a significant predictor of 5-year OS in the multivariate model (HR 1.857, 95\% CI 1.036-3.328, $\mathrm{p}=0.037$ ). Inferiority of other MDS-specific indexes to predict the outcome for allo-HSCT seems to be associated with adverse results in the intermediate risk group. In conclusion, we presume a need for further characterization of the intermediate risk patients when predicting the therapy outcomes.

\section{Keywords}

Myelodysplastic syndrome, allogeneic hematopoietic stem cell transplantation, prognostic indexes, risk estimation. 


\section{Introduction}

Myelodysplastic syndrome (MDS) is a heterogeneous group of clonal bone marrow disorders characterized by ineffective hematopoiesis, and increased propensity to evolve to acute myeloid leukemia (AML). Currently allogeneic hematopoietic stem cell transplantation (allo-HSCT) is the only treatment option with curative potential in MDS patients. However, allo-HSCT is associated with risk of significant toxicity 1-year non-relapse mortality (NRM) is reaching $17 \%$ to $25 \%$ $[1,2]$. Thereby transplant- and disease-related risks should be carefully weighed against the benefits of transplantation. Several prognostic scoring indexes such as International prognostic scoring system (IPSS) [3], revised IPSS [4], WHO-classification-based IPSS (WPSS) [5] are widely used to predict MDS disease course and optimize timing of allo-HSCT according to disease related factors. Allo-HSCT is indicated in patients with high/very high and even in very low/ low or intermediate IPSS-R risk with poor features (poor risk cytogenetics, life-threatening cytopenias, severe transfusion dependence and persistently increasing blast count) [6]. Multiparametric prognostic models IPSS, WPSS and IPSS-R were developed to assess disease risk at diagnosis. In contrast disease related index (DRI) [7] and prognostic models defined by Kroeger et al. [8] and Armand et al. [9] were designed directly for the posttransplant outcome evaluation. Patient-related risk factors such as comorbidities and age should be also taken into consideration. They are included in several prognostic scoring systems such as EBMT score [10], Pretransplant Assessment of Mortality score (PAM) [11] or Hematopoietic Cell Transplantation-specific Comorbidity Index HCT-CI [12]. Here we evaluate aforementioned disease- and transplant-related prognostic indexes in MDS patients treated with allo-HSCT in one center.

\section{Patients and methods}

All consecutive primary allogeneic transplants performed for the diagnosis MDS in the time period 2002-2018 and complete information to calculate all of the prognostic indexes were included in the analysis. Pediatric patients and patients transformed to AML were excluded. Main patient characteristics, transplantation parameters, outcomes and complications are summarized in Table 1.

Median of age was 44 years (range 18-67). Twenty four percent of patients were grafted from a matched related donor, and $73 \%$ were transplanted from the 9-10/10 HLA-matched unrelated donors. MDS with excess blasts I or II was documented in seventy-six percent of the patients. Twenty-two percent were treated with hypomethylating drugs before transplant. Conditioning regimen was myeloablative in $1 / 4$ of patients, and consisted of oral busulfan $16 \mathrm{mg} / \mathrm{kg}$ and cyclophosphamide $120 \mathrm{mg} / \mathrm{kg}$. Reduced-intensity conditioning comprised fludarabine $180 \mathrm{mg} / \mathrm{m}^{2}$ and oral busulfan $8-10 \mathrm{mg} / \mathrm{kg}$. The reduced-intensity conditioning was used in all the patients after first analysis of the RICMAC trial [2] in 2012. Graft-versus-host disease (GVHD) prophylaxis included posttransplant cyclophosphamide in $37 \%$ of patients, while the rest of them received calcineurin-based prophylaxis with short-course methotrexate, or mycophenolate mofetil and antithymocyte globulin in case of unrelated grafts.

\section{Clinical outcomes}

Time-to-disease relapse, acute GVHD (aGVHD), moderate to severe GVHD (chGVHD), non-relapse mortality (NRM), overall survival (OS), event-free survival (EFS), and GVHD-relapse free survival (GRFS) were defined as the time from transplantation to the event. Graft failure without evidence of the disease after transplantation was not considered an event. Patients were censored at the time of last contact or a second transplantation for all outcomes. The disease relapse was defined as morphologic or cytogenetic evidence of disease with pre-transplant characteristics. Disease staging, including bone marrow aspirate, was routinely performed on days $+30,+60,+100,+180,+365$ post-transplant. Primary graft failure was defined as the complete absence of donor chimerism in bone marrow aspirate by day +40 . Time to engraftment was calculated as time from HSCT to unsupported neutrophil count $>500 / \mathrm{ul}$ and white blood cell count $>1000 / \mathrm{ul}$ for 3 consecutive days. Toxicity was assessed with CTCAE ver. 4.03. Sepsis and severe sepsis were diagnosed based on International Guidelines for Management of Severe Sepsis and Septic Shock [13]. Invasive mycosis was diagnosed in case of probable or proven infection according to EORTC/MSG guidelines [14]. HCT-CI [12], DRI [7], IPSS [3], IPSS-R [4], WPSS [5], PAM [11], Armand et al. risk score [9], Kroeger et al. risk score [8] were calculated based on the published scoring systems.

\section{Statistical Analysis}

All tests were two-sided, and differences with $\mathrm{p}$ values less than 0.05 were considered significant. The difference in grading between indexes was accessed using Friedman test. The survival distributions for OS, EFS, GRFS were calculated using Kaplan-Meier methodology with 95\% confidence intervals. Appropriate survival curves are provided in Supplementary files (see online version) Cumulative incidence analysis with competing risks was used for relapse and NRM. Five-year OS was used as an outcome to test all prognostic systems, because most of them were created based overall survival with follow up for 5 years and more $[3,4,5,9]$. The univariate comparisons were made using the log-rank test. Proportional hazard modeling was used for the multivariate analysis. Based on the number of events 3 most significant factors from univariate analysis were included in the model. The MDS risk indexes were added in the series of tests. The final multivariate confidence intervals are the result of meta-analysis with fixed effect modeling. The heterogeneity of confidence intervals was tested with Cochran Q test. The C-statistic for the predictive factors was produced from logistic regression with death during five years after transplantation as an outcome. The predictive values were presented as area under the curve (AUC) with confidence intervals. Analyses were conducted in R 3.4.1 and SAS 9.3 (SAS Institute, Inc.). 
Table 1. Patient characteristics and overall transplantation outcomes

\begin{tabular}{|c|c|}
\hline Characteristic & Value \\
\hline Patient median age, y (range) & $44(18-67)$ \\
\hline Median no. of CD34 infused stem cells/kg BW (range) & $4.6 \times 10^{6}(1.4-16.4)$ \\
\hline Sex of patient, M/F & $30 / 29$ \\
\hline \multicolumn{2}{|l|}{ Donor type } \\
\hline Related & $14(24 \%)$ \\
\hline Unrelated & $43(73 \%)$ \\
\hline Haploidentical & $2(3 \%)$ \\
\hline \multicolumn{2}{|l|}{ HLA matching } \\
\hline Full & $48(81 \%)$ \\
\hline Single mismatch & $11(19 \%)$ \\
\hline \multicolumn{2}{|l|}{ Disease status } \\
\hline MDS with ring sideroblasts (MDS-RS) & $4(7 \%)$ \\
\hline MDS-RS and multilineage dysplasia & $1(2 \%)$ \\
\hline MDS with multilineage dysplasia & $4(7 \%)$ \\
\hline MDS with isolated del(5q) & $1(2 \%)$ \\
\hline MDS with excess blasts 1 & $12(20 \%)$ \\
\hline MDS with excess blasts 2 & $33(56 \%)$ \\
\hline MDS, unclassifiable & $2(3 \%)$ \\
\hline Chronic myelomonocytic leukemia & $2(3 \%)$ \\
\hline \multicolumn{2}{|l|}{ Risk profile according to IPSS score } \\
\hline Low & $4(7 \%)$ \\
\hline Intermediate-1 & 20 (34\%) \\
\hline Intermediate-2 & $23(39 \%)$ \\
\hline High & $12(20 \%)$ \\
\hline \multicolumn{2}{|l|}{ Risk profile according to IPSS-R score } \\
\hline Very low/Low & $8(14 \%)$ \\
\hline Intermediate & $19(32 \%)$ \\
\hline High & 19 (32\%) \\
\hline Very high & $13(22 \%)$ \\
\hline \multicolumn{2}{|l|}{ Risk profile according to WPSS score } \\
\hline Very low & $1(2 \%)$ \\
\hline Low & $4(7 \%)$ \\
\hline Intermediate & $9(15 \%)$ \\
\hline High & $26(44 \%)$ \\
\hline Very high & $19(32 \%)$ \\
\hline \multicolumn{2}{|l|}{ Risk profile according to Kroeger et al. score } \\
\hline Low & $15(25 \%)$ \\
\hline Intermediate & $27(46 \%)$ \\
\hline High & $13(22 \%)$ \\
\hline Very high & $4(7 \%)$ \\
\hline \multicolumn{2}{|l|}{ Risk profile according to Armand et al. score } \\
\hline Low & 31 (53\%) \\
\hline Intermediate & $19(32 \%)$ \\
\hline High & $9(15 \%)$ \\
\hline \multicolumn{2}{|l|}{ Risk profile according to PAM score } \\
\hline Score $<10$ & $11(20 \%)$ \\
\hline Score $\geq 10$ & $43(80 \%)$ \\
\hline
\end{tabular}


CLINICAL STUDIES

\begin{tabular}{|c|c|}
\hline Characteristic & Value \\
\hline \multicolumn{2}{|l|}{ Risk profile according to DRI score } \\
\hline Intermediate & $33(56 \%)$ \\
\hline High & $19(32 \%)$ \\
\hline Very high & $7(12 \%)$ \\
\hline \multicolumn{2}{|l|}{ Risk profile according to HCT-Cl score } \\
\hline Score 0 & $32(54 \%)$ \\
\hline Score $\geq 1$ & $27(46 \%)$ \\
\hline \multicolumn{2}{|l|}{ Risk profile according to EBMT score } \\
\hline Score 0 & $0(0 \%)$ \\
\hline Score 1 & $2(3 \%)$ \\
\hline Score 2 & $6(11 \%)$ \\
\hline Score 3 & $5(8 \%)$ \\
\hline Score 4 & $15(25 \%)$ \\
\hline Score 5 & 18 (31\%) \\
\hline Score $\geq 6$ & $13(22 \%)$ \\
\hline \multicolumn{2}{|l|}{ Conditioning } \\
\hline Reduced intensity & $44(75 \%)$ \\
\hline Myeloablative & $15(25 \%)$ \\
\hline \multicolumn{2}{|l|}{ AGVHD prophylaxis } \\
\hline Cyclosporine A & $10(17 \%)$ \\
\hline Tacrolimus & $42(71 \%)$ \\
\hline Methotrexate & $17(29 \%)$ \\
\hline Posttransplant cyclophosphamide & $22(37 \%)$ \\
\hline Antithymocyte globulin & $33(56 \%)$ \\
\hline AGVHD & $51 \%$ \\
\hline Grade $0-2$ & $35 \%$ \\
\hline Grade 3-4 & $15 \%$ \\
\hline Chronic graft-versus-host disease & $30 \%$ \\
\hline Limited & $2 \%$ \\
\hline Extensive & $28 \%$ \\
\hline Graft failure & $9(15 \%)$ \\
\hline \multicolumn{2}{|l|}{ Toxicity grade 3-4 } \\
\hline Liver & $9(15 \%)$ \\
\hline Renal & $2(3 \%)$ \\
\hline Mucositis & $8(15 \%)$ \\
\hline Neurotoxicity & $1(2 \%)$ \\
\hline Thrombotic microangiopathy & $3(6 \%)$ \\
\hline Hemorrhagic cystitis & $4(7 \%)$ \\
\hline Veno-occlusive disease & $3(6 \%)$ \\
\hline Sepsis & $13(24 \%)$ \\
\hline Severe sepsis & $7(13 \%)$ \\
\hline Invasive fungal infection after bone marrow transplant & 10 (18\%) \\
\hline Cytomegalovirus reactivation & $25(46 \%)$ \\
\hline
\end{tabular}




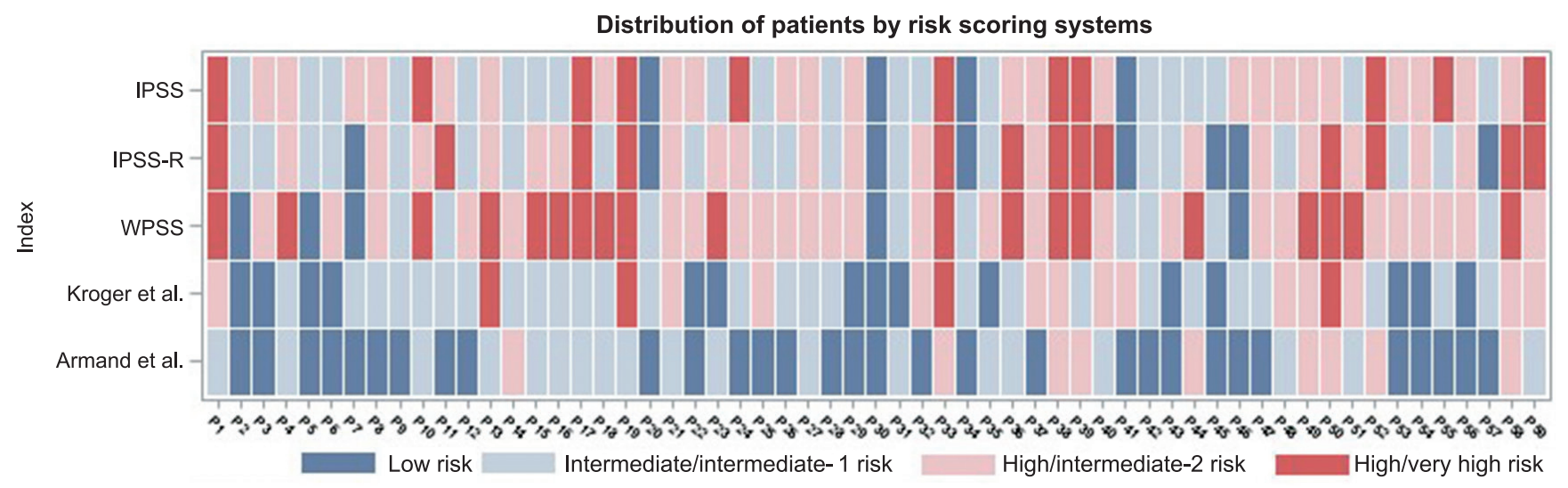

Figure 1. Distribution of patients by different prognostic scoring systems

\section{Results}

\section{Distribution of patients by different scoring systems}

We analyzed the distribution of patients by disease specific scoring systems such as IPSS, WPSS and IPSS-R and MDS prognostic indexes for patients undergoing allo-HSCT developed by Kroeger et al. and Armand et al. (Fig. 1). Fiftyfour percent of patients were transplanted in high or very high IPSS-R risk. Forty-eight percent of patients with high/ very high WPSS or IPSS-R risk were reclassified into intermediate risk according to pretransplant Kroeger et al. MDS score and $60 \%$ into intermediate risk, according to pretransplant Armand et al. score. There was a difference between disease- and pretransplant prognostic systems especially in distinction between high/very high and intermediate risk $(\mathrm{p}<0.001)$.

\section{Clinical outcomes}

Platelet and leukocyte engraftment was documented in 48 (81\%) of patients. Primary graft failure was observed in six cases (10\%). Four patients out of them died (in one case, due to disease progression, and three patients deceased due to infections). The median time to leukocyte engraftment was 18 days (range 11-30), neutrophil engraftment, 20 days (range 10-30), platelet engraftment, 17 days (range 11-130). Overall, $50 \%$ of patients developed aGVHD with severe aGVHD grade 3-4 registered only in $15 \%$ of cases. The rate of chronic GVHD was $30 \%$, which proved to be extensive in $28 \%$ of the patients (Table 1).

Cumulative incidence of relapse at 5 years was 37\% (95\% CI $25-57 \%)$. The cumulative incidence of non-relapse mortality (NRM) at 1 year was 25\% (95\% CI 16-40\%). Thirty patients died during the follow-up study. The main reasons of death were disease progression or relapse in $26 \%$; GVHD, 26\%; infections, 37\%; hemorrhagic events, 7\%; acute myocardial infarction, in $4 \%$ of cases.

With a median follow-up of 36 months (range 3 to 135), the 5 -year OS, EFS and GRFS was 34\%, 33\% and 29\%, respectively. In univariate analysis, the significant factors for prolonged OS were as follows: aGVHD grade 1-2 (62\% vs $18 \%$ $\mathrm{p}=0.004)$, quantities of donor CD34+ cells $(\mathrm{p}=0.006)$, and absence of septic episodes before engraftment (44\%vs 17\%,

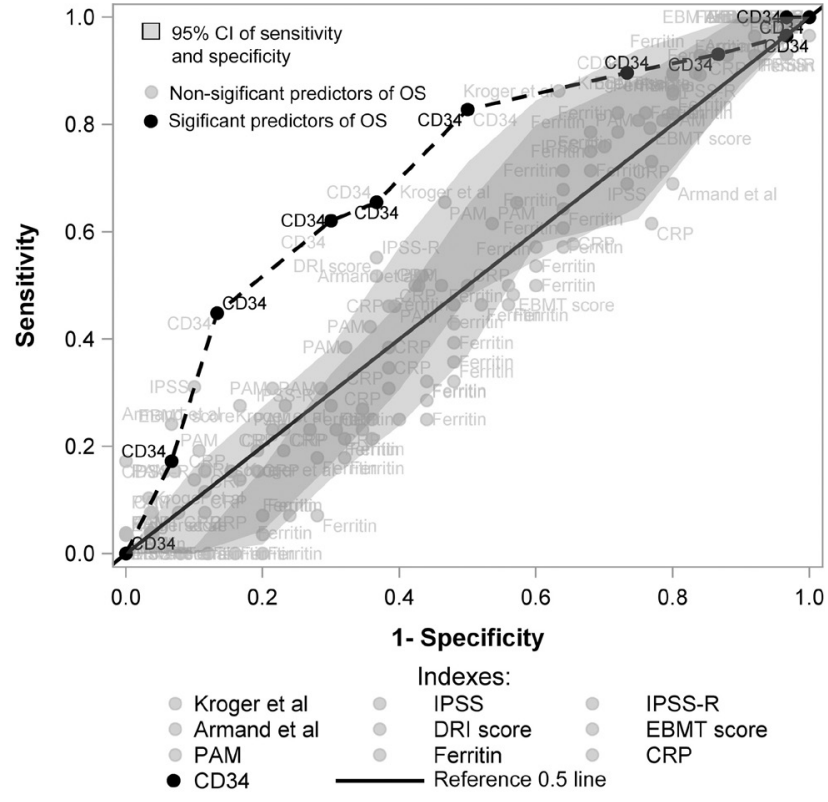

Figure 2. Influence of different prognostic systems and factors on $0 S$ in MDS patients, receiver-operating-curve (ROC) analysis

Note: C-statistics for the potential predictors of overall survival. Results of the ROC analysis treated in logistic regression with 5-year overall survival as an outcome. The non-significant parameters $(\mathrm{p}>0.05)$ are shown in grey. The significant $(p<0.05)$ parameters are shown in black. The $95 \%$ confidence intervals of sensitivity and specificity are produced from individual results of all the parameters tested. C-statistic values of the variables were: CD34 positive cells in the graft 0.7080 (95\% CI 0.5740-0.8421), Kroger et al. 0.5862 (95\% CI 0.4391-0.7333), Armand et al. 0.5339 (95\% CI 0.3850-0.6828), IPSS 0.5534 (95\% CI 0.4121-0.6948), WPSS 0.5672 (95\% CI $0.4354-0.6991)$, IPSS-R 0.5885 (0.4430$0.7340)$, DRI 0.5747 (0.4429-0.7065), EBMT 0.5230 (0.3758$0.6702)$, serum ferritin 0.4500 (0.2861-0.6139), PAM index 0.5584 (0.4037-0.7131), CRP before conditioning 0.4845 (0.3234-0.6456). 
$\mathrm{p}=0.003$ ). The disease-specific prognostic indexes (IPSS, WPSS, IPSS-R), and transplant comorbidity indexes (PAM, EBMT, HCT-CI) did not predict OS . However, differences in OS rates between the risk groups according to disease-related prognostic systems such as Disease-Related Index, DRI $(\mathrm{p}=0.049)$, and risk score by Kroeger et al. $(\mathrm{p}=0.071)$ have shown a trend towards statistical significance (Supplement, Fig. 1-7. The supplemental files could be found in electronic version of this paper at www.cttjournal.com). The 5-year OS in low risk group, according to transplant risk score proposed by Kroeger et al. was $61 \%$, thus being significantly higher compared to intermediate and high/very high risk $26 \%(\mathrm{p}=0.041)$. Surprisingly, we found no difference in OS between intermediate and high/very high risk groups $(28 \%$ and $22 \%$, respectively). This might be a reason for the failure of the index used by Kroeger et al. to achieve statistical significance. Interestingly, that the causes of death were nearly the same in both risk groups, i.e., ca. $50 \%$ of patients died due to transplant related factors.

ROC analysis shows influence of different prognostic systems and factors upon OS in the MDS patients. Amount of transplanted CD34+ donor cells proved to be the only factor which significantly affected transplant outcome $(\mathrm{p}=0.006)$ in this analysis (Fig. 2).

However, only presence of aGVHD grade $1-2(\mathrm{p}=0.013)$, absence of septic episodes $(p=0.006)$, and DRI $(p=0.037)$ retained their statistical significance in the multivariate analysis (Fig. 3). Other prognostic scores, except of DRI, did not show a statistical significance.

\section{Discussion}

The major question in every MDS patient with currently existing treatments is whether he will benefit from allo-HSCT. Despite the fact that all existing treatments in most cases lead to only temporary responses, the results of allo-HSCT in MDS unfortunately are also one of the most disappointing compared to other diseases [15]. According to our 5-year observation data, the OS level in allotransplanted MDS patients is $34 \%$. The other studies are showing nearly the same results: from $45 \%$ to $37 \%[1,16]$. This is due to relatively high NRM [3], but also due to high relapse rate $[2,17]$. Currently used indexes of the natural course of the disease such as IPSS, WPSS, IPSS-R are established to evaluate risk of death and transformation to acute myeloid leukemia in untreated MDS patients $[3,4,5]$. All of these indexes are well validated in large patient cohorts [17]. However, their role in predicting the outcome after allo-HSCT is not so well defined.

Lee et al. [18] evaluated prognostic impact of IPSS before allo-HSCT. The authors showed significant differences in OS after allo-HSCT between low/intermediate and intermediate/high groups. Further it was shown that WPSS has a relevant prognostic value in posttransplant outcome of patients with MDS [19]. Modified prognostic model IPSS-R was assessed pre-transplant as a predictor of transplant outcome by C. Scheid et al. [20]. In that study, IPSS-R significantly influenced OS after allo-HSCT, but OS in high and intermediate groups were comparable: $47 \%$ and $44 \%$, respectively. This was due to high and comparable NRM in these groups.

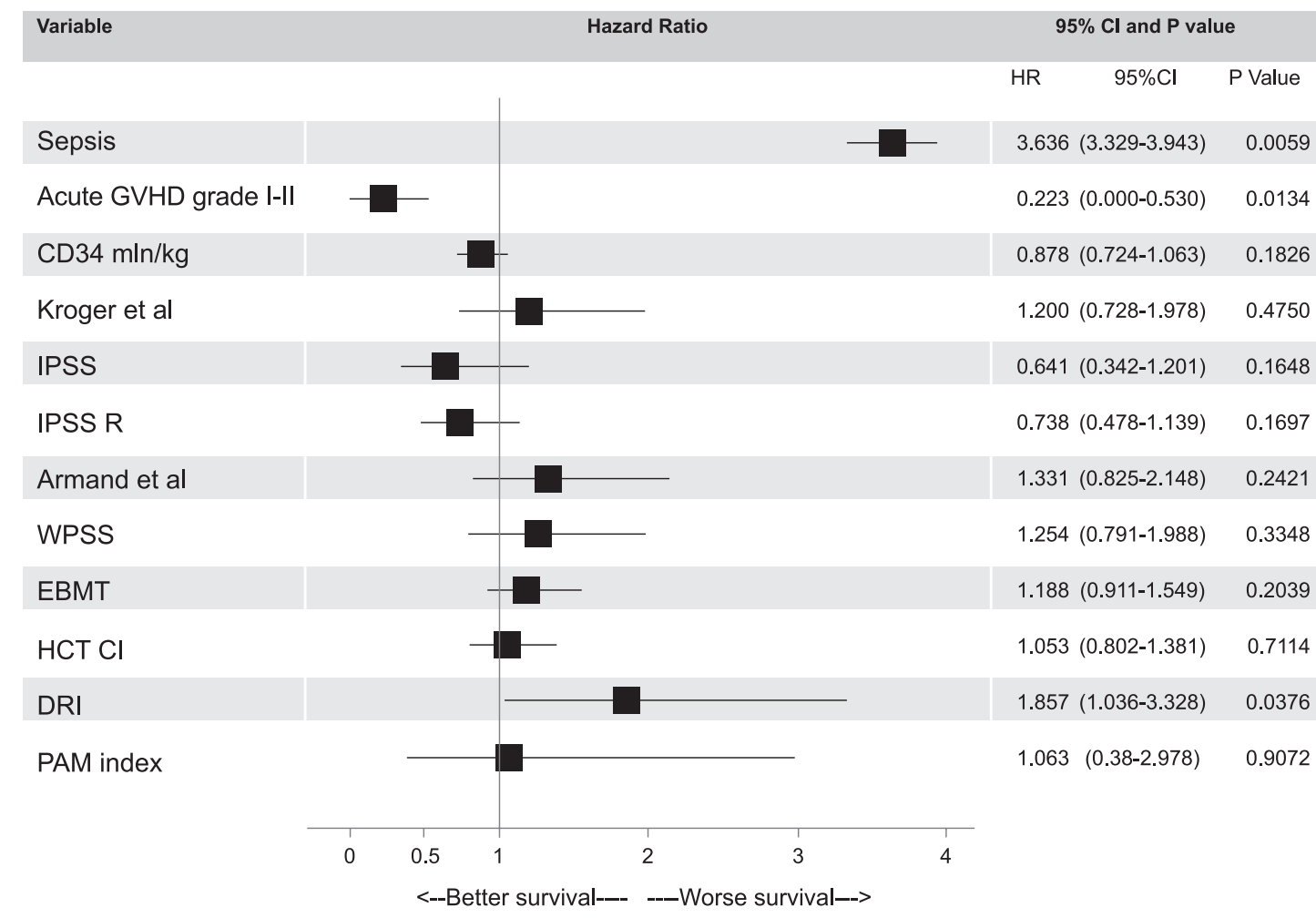

\section{Figure 3. Analysis of the prognostic value of risk indexes in the multivariate model}

Note: Multivariate analysis of overall survival. Acute GVHD, graft CD34+ cells and sepsis in aplasia were included based on univariate selection of the most predictive variables. The indexes were added as the fourth co-variable separately in a series of tests. The cumulative confidence intervals for the clinical variables were produced with fixed effect model from the individual hazards in the series. 
In our study we have also observed high NRM in the favorable prognostic groups based on IPSS or IPSS-R.

The potential causes for early mortality in this group are relatively well discussed in the literature. They include primary graft failure [21], iron overload which results in higher incidence of liver veno-occlusive disease [22] and infectious complications [23]. It should be noted that, according to our data, the rate of primary graft failure is $10 \%$ being considered relatively high. The incidence of graft failure varies from 2 to $13 \%[2,16,24]$. We didn't find any correlation between rate of graft failure and type of stem cell source or rate of CD34+ cells in the graft, as reported in previous studies [21]. According to the results of large study by Olsson et al. [21], MDS diagnosis itself is associated with increased risk of graft failure, along with other hematologic malignancies, e.g., myeloproliferative disorders and chronic lymphocytic leukemia. Poor graft function may be another documented cause of NRM that leads to increased incidence of opportunistic infections and hemorrhagic complications [25]. Thus, high NRM rate was the main reason of non-significant predictive value of classical indexes after allo-HSCT found in our study.

A number of indexes accounting for NRM based on previous treatment burden, like as duration of the disease in EBMT index, or comorbidity burden, like in HCT-CI, or prediction of viral reactivations based on serological markers, like in PAM. However, there are conflicting results about influence of the comorbidity indexes on OS in MDS patients. Guilfoyle et al. did not find associations between HCT-CI and OS in MDS patients [26]. On the other hand, a large retrospective study showed that EBMT score accurately predicted OS and NRM [27]. In the present study, we have not observed any predictive impact of these indexes on the disease outcome. The published data and results of our study indicate that biological mechanisms behind NRM might be in certain cases different in MDS compared to the other diseases [28].

Several new prognostic indexes have been recently developed aiming for precise evaluation of transplant outcome in MDS patients. Kroeger et al. have combined the disease-related factors (cytogenetics, blood blasts, and platelets) and patient-related factors (performance status and age) into a common prognostic system [8]. Armand et al. added ferritin level and type of a conditioning regimen to the disease-related risk factors [9]. The disease risk index was another prognostic system evaluated in our study. It includes cytogenetics and remission status of MDS patients at transplant [7]. These indexes, except of DRI, were assessed in large data sets to specifically account for the risk of relapse and the risk of NRM. There is only a limited number of studies validating these indexes [29]. Interestingly, about half of IPSS-R high/ very high risk patients were reclassified as more favorable category, the intermediate-1, according to risk score by Kroeger et al. and Armand et al. [8,9]. Thereby, the disease- and transplant-specific scoring systems determine the transplant outcome in different ways. According to our data, only DRI significantly influenced OS values among all the mentioned prognostic scores. In our study, these transplant-specific indexes were shown to define well the group with good prognosis and adverse prognosis. However, we observed that clinical prognosis for the intermediate group proved to be as adverse as for the high-risk patients.
Thus, our study indicates that current prognostic indexes do not well define the intermediate prognosis. It is likely that most of the heterogeneity of the disease fall into this category, including patients with stromal and miRNA signaling deficiency [30], pyroptosis of hematopoietic stem cells [31], certain mutations without cytogenetic abnormalities [32]. Any of these pathogenetic variants might manifest in different mechanisms of NRM and relapse risk. Pooling the patients into large cohorts alleviate these differences by creation of risk indexes. However, small-group or individual prediction might not be so accurate, due to the causes mentioned above. Thus, future development of indexes and predictive systems for allo-HSCT should incorporate molecular data, at least, for the intermediate risk groups in MDS.

\section{Conclusion}

In our relatively small single-center study, we have observed little predictive value of currently existing scoring systems, particularly due to adverse results in the intermediate risk patients. Further characterization of this "intermediate" patents is required to broaden the clinical application of the scoring systems for individual treatment planning.

\section{Acknowledgments}

We thank our patients, research and medical staff for making this study possible. This work was done as part of Russian Science Foundation grant №17-75-20145.

\section{Disclosure statement}

Authors confirm the absence of any conflicts of interests.

\section{References}

1. Luger SM, Ringdén O, Zhang MJ, Pérez WS, Bishop MR, Bornhauser M, Bredeson CN, Cairo MS, Copelan EA, Gale RP, Giralt SA, Gulbas Z, Gupta V, Hale GA, Lazarus HM, et al. Similar outcomes using myeloablative vs reduced-intensity allogeneic transplant preparative regimens for AML or MDS. Bone Marrow Transplant. 2012;47(2):203-211.

2. Kröger N, Iacobelli S, Franke GN, Platzbecker U, Uddin R, Hübel K, Scheid C, Weber T, Robin M, Stelljes M, Afanasyev B, Heim D, Deliliers GL, Onida F, Dreger P, et al. Dose-reduced versus standard conditioning followed by allogeneic stem-cell transplantation for patients with myelodysplastic syndrome: a prospective randomized phase III study of the EBMT (RICMAC Trial). J Clin Oncol. 2017;35(19):21572164.

3. Greenberg P, Cox C, LeBeau MM, Fenaux P, Morel P, Sanz G, Sanz M, Vallespi T, Hamblin T, Oscier D, Ohyashiki K, Toyama K, Aul C, Mufti G, Bennett J. International scoring system for evaluating prognosis in myelodysplastic syndromes. Blood. 1997;89(6):2079-2088.

4. Greenberg PL, Tuechler H, Schanz J, Sanz G, GarciaManero G, Solé F, Bennett JM, Bowen D, Fenaux P, Dreyfus F, Kantarjian H, Kuendgen A, Levis A, Malcovati L, Cazzola $\mathrm{M}$, et al. Revised international prognostic scoring system for myelodysplastic syndromes. Blood. 2012; 120(12):2454-2465. 
5. Malcovati L, Germing U, Kuendgen A, Della Porta MG, Pascutto C, Invernizzi R, Giagounidis A, Hildebrandt B, Bernasconi P, Knipp S, Strupp C, Lazzarino M, Aul C, Cazzola M., et al. Time-dependent prognostic scoring system for predicting survival and leukemic evolution in myelodysplastic syndromes. J Clin Oncol. 2007;25(23):3503-3510.

6. de Witte T, Bowen D, Robin M, Malcovati L, Niederwieser D, Yakoub-Agha I, Mufti GJ, Fenaux P, Sanz G, Martino R, Alessandrino EP, Onida F, Symeonidis A, Passweg J, Kobbe G, Ganser A, et al. Allogeneic hematopoietic stem cell transplantation for MDS and CMML: recommendations from an international expert panel. Blood. 2017;129(13):1753-1762.

7. Armand P, Kim HT, Logan BR, Wang Z, Alyea EP, Kalaycio ME, Maziarz RT, Antin JH, Soiffer RJ, Weisdorf DJ, Rizzo JD, Horowitz MM, Saber W, et al. Validation and refinement of the Disease Risk Index for allogeneic stem cell transplantation. Blood. 2014;123(23):3664-3671.

8. Gagelmann N, Eikema DJ, Stelljes M, Beelen D, de Wreede L, Mufti G, Knelange NS, Niederwieser D, Friis LS, Ehnninger G, Nagler A, Yakoub-Agha I, Meijer E, Ljungman P, Maertens J, et al. Optimized EBMT transplant-specific risk score in myelodysplastic syndromes after allogeneic stem-cell transplantation. Haematologica. 2019. pii: haematol.2018.200808. doi: 10.3324/haematol.2018.200808.

9. Armand P, Kim HT, Cutler CS, Ho VT, Koreth J, Ritz J, Alyea EP, Antin JH, Soiffer RJ. A prognostic score for patients with acute leukemia or myelodysplastic syndromes undergoing allogeneic stem cell transplantation. Biol Blood Marrow Transplant. 2008;14(1):28-35.

10. Gratwohl A. The EBMT risk score. Bone Marrow Transplant. 2012;47(6):749-756.

11. Au BK, Gooley TA, Armand P, Fang M, Madtes DK, Sorror ML, Boeckh MJ, Gibson CJ, Deeg HJ, Storb R, Appelbaum FR, Chien JW, Martin PJ. Reevaluation of the Pretransplant Assessment of Mortality score after allogeneic hematopoietic transplantation. Biol Blood Marrow Transplant. 2015;21(5):848-854.

12. Sorror ML, Maris MB, Storb R, Baron F, Sandmaier BM, Maloney DG, Storer B. Hematopoietic cell transplantation (HCT)-specific comorbidity index: a new tool for risk assessment before allogeneic HCT. Blood. 2005;106(8):2912-2919.

13. Singer M, Deutschman CS, Seymour CW, Shankar-Hari M, Annane D, Bauer M, Bellomo R, Bernard GR, Chiche JD, Coopersmith CM, Hotchkiss RS, Levy MM, Marshall JC, Martin GS, Opal SM, et al. The third international consensus definitions for sepsis and septic shock. JAMA. 2016;315(8):801-810.

14. De Pauw B, Walsh TJ, Donnelly JP, Stevens DA, Edwards JE, Calandra T, Pappas PG, Maertens J, Lortholary O, Kauffman CA, Denning DW, Patterson TF, Maschmeyer G, Bille J, Dismukes WE, et al. Revised definitions of invasive fungal disease from the European Organization for Research and Treatment of Cancer/invasive fungal infections cooperative group and the National Institute of Allergy and Infectious Diseases Mycoses Study Group (EORTC/MSG) Consensus Group. Clin Infect Dis. 2008;46(12):1813-1821.
15. Raiola A, Dominietto A, Varaldo R, Ghiso A, Galaverna F, Bramanti S, Todisco E, Sarina B, Giordano L, Ibatici A, Santoro A, Clavio M, Bacigalupo A, Castagna L. Unmanipulated haploidentical BMT following non-myeloablative conditioning and post-transplantation CY for advanced Hodgkin's lymphoma. Bone Marrow Transplant. 2014;49(2):190-194.

16. Litzow MR, Tarima S, Pérez WS, Bolwell BJ, Cairo MS, Camitta BM, Cutler CS, de Lima M, Dipersio JF, Gale RP, Keating A, Lazarus HM, Luger S, Marks DI, Maziarz RT, et al. Allogeneic transplantation for therapy-related myelodysplastic syndrome and acute myeloid leukemia. Blood. 2016;115(9):1850-1858.

17. Della Porta MG, Tuechler H, Malcovati L, Schanz J, Sanz G, Garcia-Manero G, Solé F, Bennett JM, Bowen D, Fenaux P, Dreyfus F, Kantarjian H, Kuendgen A, Levis A, Cermak J, et al. Validation of WHO classification-based Prognostic Scoring System (WPSS) for myelodysplastic syndromes and comparison with the revised International Prognostic Scoring System (IPSS-R). A study of the International Working Group for Prognosis in Myelodysplasia (IWG-PM). Leukemia. 2015;29(7):1502-1513.

18. Lee JH, Lee JH, Lim SN, Kim DY, Kim SH, Lee YS, Kang YA, Kang SI, Jeon MJ, Seol M, Seo EJ, Chi HS, Park CJ, Jang S, Yun SC, et al. Allogeneic hematopoietic cell transplantation for myelodysplastic syndrome: Prognostic significance of pre-transplant IPSS score and comorbidity. Bone Marrow Transplant. 2010;45(3):450-457.

19. Alessandrino EP, Della Porta MG, Bacigalupo A, Van Lint MT, Falda M, Onida F, Bernardi M, Iori AP, Rambaldi A, Cerretti R, Marenco P, Pioltelli P, Malcovati L, Pascutto C, Oneto R, et al. WHO classification and WPSS predict posttransplantation outcome in patients with myelodysplastic syndrome: a study from the Gruppo ItalianoTrapianto di Midollo Osseo (GITMO). Blood.2008;112(3):895-902.

20. Scheid C, de Wreede L, van Biezen A, Koenecke C, Göhring G, Volin L, Maertens J, Finke J, Passweg J, Beelen D, Cornelissen JJ, Itälä-Remes M, Chevallier P, Russell N, Petersen E, et al. Validation of the revised IPSS at transplant in patients with myelodysplastic syndrome/transformed acute myelogenous leukemia receiving allogeneic stem cell transplantation: A retrospective analysis of the EBMT chronic malignancies working party. Bone Marrow Transplant. 2017;52(11):1519-1525.

21. Olsson RF, Logan BR, Chaudhury S, Zhu X, Akpek G, Bolwell BJ, Bredeson CN, Dvorak CC, Gupta V, Ho VT, Lazarus HM, Marks DI, Ringdén OT, Pasquini MC, Schriber JR, et al. Primary graft failure after myeloablative allogeneic hematopoietic cell transplantation for hematologic malignancies Leukemia. 2015;29(8):1754-1762.

22. Armand P, Kim HT, Cutler CS, Ho VT, Koreth J, Alyea EP, Soiffer RJ, Antin JH. Prognostic impact of elevated pretransplantation serum ferritin in patients undergoing myeloablative stem cell transplantation. Blood. 2007;109(10):45864588 .

23. Shaheen M, Ivanova MO, Moiseev IS, Bondarchuk SV, Afanasyev BV. Impact of initial serum ferritin on early postHSCT complications: A single-center study. Cell Ther Transplant. 2016;5(2):40-48. 
24. Castro-Malaspina H, Harris RE, Gajewski J, Ramsay N, Collins R, Dharan B, King R, Deeg HJ. Unrelated donor marrow transplantation for myelodysplastic syndromes: Outcome analysis in 510 transplants facilitated by the National Marrow Donor Program. Blood.2002;99(6):1943-1951.

25. Shimomura Y, Hara M, Katoh D, Hashimoto H, Ishikawa T. Enlarged spleen is associated with low neutrophil and platelet engraftment rates and poor survival after allogeneic stem cell transplantation in patients with acute myeloid leukemia and myelodysplastic syndrome. Ann Hematol. 2018;97(6):1049-1056.

26. Guilfoyle R, Demers A, Bredeson C, Richardson E, Rubinger M, Szwajcer D, Seftel MD. Performance status, but not the Hematopoietic Cell Transplantation Comorbidity Index (HCT-CI), predicts mortality at a Canadian transplant center. Bone Marrow Transplant. 2009;43(2):133-139.

27. Lozano S, Olavarria E, Iacobelli S, van Biezen A, Beelen DW, Finke J, Mufti GJ, Niederwieser D, Ehninger G, Ganser A, Stuhler G, Maertens J, Bacigalupo A, Volin L, Nagler A et al. The EBMT score predicts transplant related mortality and overall survival after allogeneic stem cell transplantation for myelodysplastic syndromes [Abstract]. Proc ASH. 2015, 3223.

28. Ferrer RA, Wobus M, List C, Wehner R, Schönefeldt C, Brocard B, Mohr B, Rauner M, Schmitz M, Stiehler M, Ehninger G, Hofbauer LC, Bornhäuser M, Platzbecker U. Mesenchymal stromal cells from patients with myelodyplastic syndrome display distinct functional alterations that are modulated by lenalidomide. Haematologica. 2013;98(11):1677-1685.

29. Beauverd Y, Roosnek E, Tirefort Y, Nagy-Hulliger M, Bernimoulin M, Tsopra O, Ansari M, Dantin C, Casini A, Grandjean AP, Chigrinova E, Masouridi-Levrat S, Chalandon Y. Validation of the disease risk index for outcome of patients undergoing allogeneic hematopoietic stem cell transplantation after T cell depletion. Biol Blood Marrow Transplant. 2014;20(9):1322-1328.

30. Zhao Y, Wu D, Fei C, Guo J, Gu S, Zhu Y, Xu F, Zhang Z, Wu L, Li X, Chang C. Down-regulation of Dicer1 promotes cellular senescence and decreases the differentiation and stem cell-supporting capacities of mesenchymal stromal cells in patients with myelodysplastic syndrome. Haematologica. 2015;100(2):194-204.

31. Basiorka AA, McGraw KL, Eksioglu EA, Chen X, Johnson J, Zhang L, Zhang Q, Irvine BA, Cluzeau T, Sallman DA, Padron E, Komrokji R, Sokol L, Coll RC, Robertson AA, et al. The NLRP3 inflammasome functions as a driver of the myelodysplastic syndrome phenotype. Blood. 2016;128(25):2960-2975.

32. Yoshizato T, Nannya Y, Atsuta Y, Shiozawa Y, IijimaYamashita Y, Yoshida K, Shiraishi Y, Suzuki H, Nagata Y, Sato Y, Kakiuchi N, Matsuo K, Onizuka M, Kataoka K, Chiba K, et al. Genetic abnormalities in myelodysplasia and secondary acute myeloid leukemia: impact on outcome of stem cell transplantation. Blood. 2017;129(17):2347-2358. 


\section{Применение стандартных и новых прогностических систем у больных с миелодиспластическим синдро- мом, подлежащих аллогенной трансплантации гемопоэтических стволовых клеток}

Елена В. Морозова, Мария В. Барабанщикова, Николай Ю. Цветков, Ксения В. Мельситова, Юлия В. Рудницкая, Елена И. Дарская, Сергей Н. Бондаренко, Иван С. Моисеев, Борис В. Афанасьев

НИИ детской онкологии, гематологии и трансплантологии им. Р. М. Горбачевой Первого Санкт-Петербургского государственного медицинского университета им. И. П. Павлова, Санкт-Петербург, Россия

\section{Резюме}

Разработан ряд предиктивных индексов для прогнозирования исхода у пациентов с миелодиспластическим синдромом (МДС). Целью нашего исследования была оценка прогностического вклада показателей заболевания и трансплантации в результаты аллогенной трансплантации гемопоэтических клеток (ТГСК) пациентам с МДС.

\section{Пациенты и методы}

В ретроспективное исследование была включена группа из 53 пациентов с МДС (за исключением вторичного острого миелобластного лейкоза), леченных с применением алло-ТГСК. Целью работы была оценка предиктивной значимости следующих прогностических индексов: IPSS, IPSS-R, WPSS, Disease Risk Index (DRI), а также прогностической системы, предложенной Kroeger et al., Armand et al., индекса претрансплантационной оценки смертности (РАM), оценки риска по ЕВМТ и ТГСК-специфичного индекса коморбидности (НСТ-СI).

\section{Результаты}

В результате работы показана достоверная разница в оценке риска при сравнении отдельных индексов ( $\mathrm{p}<0,001)$. Были отмечены следующие клинические факторы, значимые для общей выживаемости (OB) в одно- и многофакторном анализе: острая реакция «трансплантат против хозяина» (ОРТПХ) I-II степени (HR 0,.223; 95\% CI 0.059-0,721; p=0,0134) и возникновение сепсиса в период аплазии (HR 3,636; 95\% CI 1,438-8,673; p=0,0059). Несмотря на значительный вклад числа CD34+ клеток в трансплантате, $(\mathrm{p}=0,006)$, выявленного посредством ROCанализа, только индекс DRI являлся существенным средством прогноза 5-летней выживаемости в многофакторной модели (HR 1,857; 95\% CI 1,036$3,328 ; \mathrm{p}=0,037)$. Более низкая эффективность других МДС-специфичных индексов в прогнозировании исходов алло-ТГСК связана, по-видимому, с неблагоприятными исходами в группе промежуточного риска. В заключение мы должны отметить необходимость дальнейшей характеризации пациентов промежуточной группы риска при прогнозировании исхода лечения.

\section{Ключевые слова}

Миелодиспластический синдром, аллогенная трансплантация гемопоэтических стволовых клеток, прогностические индексы, оценка риска. 